\title{
NEURAL DIFFERENTIATION OF ADIPOSE TISSUE- DERIVED MESENCHYMAL STEM CELLS
}

\author{
El-Gamal A M, Abd-Elmaksaud A, Farag A, Marei H E. \\ Department of Cytology and Histology \\ Faculty of Veterinary Medicine, Mansoura University, Egypt
}

\begin{abstract}
The limited neurodegenerative power, makes from neural disorders the most challenging and difficult therapy among different diseases. till now, the traditional surgical and medical interventions only slow down the progression of these neurodegenerative diseases but the number of neurons are still diminish in many patients.

Now, the mesenchymal stem cell (MSC) therapy has attracted the great attention of most scientists and clinicians around the world to be used as a therapeutic potential source for different neurodegenerative disorders. Stem cells have been found all over the body and can be obtained from different tissues as; adipose tissue, bone marrow and blood. MSCs characterized by high proliferation and differentiation abilities, providing a source of neurons and glia for cell replacement therapy. Also, MSCs show neuroprotective effects without any genetic modification and not show teratoma. Lately, scientist directed toward differentiation of mesenchymal stem cells toward neural cells using different growth factors and chemicals. In the current study, we have tested the effect of ATRA in a dose $10 \mu \mathrm{M}$ and heparin in a dose of 50 $\mu \mathrm{g}$ as neural inducers either for dopaminergic or cholinergic neurons. The results indicate that both retinoic acid and heparin are positively neural inducers. Also found that heparin mixed with retinoic acid give better results. These results were confirmed using RT-PCR for MAP2, $\beta$-tubulinIII, ChAT, TH neural genes markers.

Abbreviations: MSC: mesenchymal stem cells, ATRA: all-trans retinoic acid, MAP2: microtubule associated gene, ChAT: choline acetyl transeferase, TH: tyrosin hydroxylase.
\end{abstract}

\section{INTRODUCTION}

Neurodegenerative disorders are broad range of acute and/or chronic diseases by which neurons and/or glial cells of the brain and/or spinal cord are damaged. Acute conditions like; spinal cord injury or ischemic stroke may result in death of different types of neuronal cells and/or glial cells in a certain brain region over a short time interval. Chronically, there is a selective damage of a certain cell population over several years. Parkinson's disease is characterized by dopaminergic neurons loss, while motor neurons loss is manifested in patients suffering from amyotrophic lateral sclerosis. Widespread degeneration of many types of neuron is observed in Alzheimer disease. Dozens of scientific publication report the potential therapeutic applications of the stem cell based approaches for restoring the damaged brain areas in neurodegenerative disease (Lindvall $\&$ Kokaia , 2010).

After discovery of neural stem cells (NSCs), the following researches (Feng et al., 2008) have challenged the old idea that the 
adult CNS was not capable of neurogenesis. Actually, neurogenesis occurs throughout life. NSCs are believed to exist in many areas where neurogenesis occurs (Ma et al., 2009).

Therefore, usage of NSCs for treatment of neurodegenerative diseases is an interesting concept. But, the access to NSCs as a source of stem cells for possible use to treat neurodegenerative disorders is not so easy process (Dantuma et al., 2010).

Mesenchymal stem cells (MSCs) belong to the mesodermal lineage. They are tissuespecific stem cells that present in various types of mesenchymal tissues i.e., adipose tissue, bone marrow, umbilical cord, dental pulp, dermis, and synovia (Fang et al., 2007).

MSCs can differentiate in vitro into cells of other lineages including ectodermal lineages (neuronal, peripheral glial and epidermal cells) and endodermal lineages (insulin-producing cells and hepatocytes) (Prockop, 1997; Dezawa et al., 2001; Oyagi et al., 2006).

Stem cell for regenerative medicinal applications ideally should have the following criteria:

1). Abundance in numbers (millions to billions of cells)

2). Easiness of harvesting (through minimally invasive procedures)

3). Have the ability to differentiate into multiple cell lineage (which in vitro can be regulated and reproduced)

4). Harmless to transplant to a different site of the autologous or even an allogeneic host.

5). No conflict with current Good Manufacturing Principles whatever during obtaining, culture or even transplantation (Gimble, 2003).

All of these criteria are found in adipose derived mesenchymal stem cells, easy to harvest in abundant amount with low morbidity and low mortality than bone marrow derived mesenchymal stem cell and also can be transplanted into different sites of autogenic host in contrast to umbilical cord derived mesenchymal stem cell.

Based on the aforementioned information, the present study was conducted to: 1. Test the possibility of isolation of mesenchymal stem cells from adipose tisse; 2 . Differentiate mesenchymal stem cell into neurons, and 3. Study the gene expression profile for key genes specific for MSCsderived neurons using quantitative real time PCR (qRT-PCR).

\section{MATERIAL AND METHODS}

\section{Isolation of mesenchymal stem cells (MSCs) from adipose tissue:}

The lipoaspirate sample was obtained from the upper back of 40 years old female free of medical history. Informed consent was obtained according to protocols approved by the Ethical Committee of the Mansoura University. The lipoaspirated sample transferred from patient to the stem cell lab. Under complete sterile condition using biological safety cabinet class 2 , the lipoaspirated sample embedded directly into $0.075 \%$ collagenase type one and type two mixtures without cutting. The sample placed in shaking water path at $37^{\circ} \mathrm{c}$ for 30 minute then transferred into the centrifuge $(1800 \mathrm{rpm}$ $15 \mathrm{~min}$.).

After discarding the supernatant, the resultant stromal vascular reaction (SVF) was merged in $10 \mathrm{ml}$ media (Dulbecco Modified Eagle Medium (DMEM) $+10 \%$ fetal bovine serum (FBS) $+1 \%$ penicillin streptomycin) to neutralize the enzymatic activity of the collagenase followed by centrifugation at $1800 \mathrm{rpm}$ for 5 mins. The supernatant discarded and then added about $10 \mathrm{ml}$ complete media (CM) on the resultant pellet. The sample was 
maintained into humidified $\mathrm{CO} 2$ incubator at $37^{\circ} \mathrm{c}$ and $5 \% \mathrm{CO} 2$ for 3 days.

Following every $3^{\text {rd }}$ day, the media were removed via aspiration and exchanged by freshly prepared one. The cells were examined daily under inverted microscope for confluence checking.

\section{Neural induction:}

At passage 3 when cells reach confluence of $60 \%$, the media were removed and exchanged by neural induction media. The study included three groups with two different induction media; $1^{\text {st }}$ Group: neural induction media (NI 1) for 14 days and consist of: DMEM $+10 \%$ FBS $+1 \%$ antibiotic $+10 \mu \mathrm{M}$ retinoic acid. 2nd group: neural induction media (NI 2) for 15 days and consist of: $\mathrm{DMEM}+10 \% \mathrm{FBS}+1 \%$ antibiotic $+10 \mathrm{ng} / \mathrm{ml}$ $\mathrm{FGF}+50 \mu \mathrm{g} / \mathrm{ml}$ heparin. 3rd group: the control group (undifferentiated mesenchymal stem cells).

\section{Characterization of neural cell:}

Cells were assessed for the expression of specific neural genes by real time PCR. The RNA were extracted by RNA extraction kits (Thermo Scientific, Fermentas, \#K0731) then transformed it into cDNA by Reverse transcription kits (Thermo Scientific, Fermentas, \#EP0451). The nanodrop was used to be sure that the concentrations of RNA and
cDNA are pure enough to conduct the experiment. As housekeeping gene, GAPDH was used to compare with the expression of mRNAs of the target genes. Four genes were used for assessing the cellular differentiation; MAP2, $\beta$ tubulin III, ChAT, and TH markers.

\section{RESULTS}

\section{Morphological analysis:}

Primary cells adherent to the culture flask were spindle-shaped in morphology. After 14 days of induction, no significant change in cell morphology was detected in the control group (figure 1) while round or elliptical cell bodies with processes were visible in the NI 1 and NI 2 after 14 days. Simultaneously, some cells became interconnected to one another, exhibiting a neuronal-like morphology, and a few cells died.

\section{Molecular analysis:}

Real time PCR reveal up regulations in the four genes meaning that both retinoic acid and heparin is good inducers for neural induction for either cholinergic or dopaminergic neurons. Heparin mixed with FGF give good results than using retinoic acid alone.

\begin{tabular}{|c|c|c|c|}
\hline Time in days & NI 1 (14 days) & NI 2 (14 days) & Control \\
\hline After 3 days & $\begin{array}{l}\text { Some cells show enlargement with } \\
\text { obvious nucleus and few processes } \\
\text { begin to appear. }\end{array}$ & $\begin{array}{l}\text { Cells enlarged with more } \\
\text { obvious processes than } \\
\text { observed in NI } 1 \text { and NI } 2 .\end{array}$ & fibroblastic \\
\hline After 6 days & $\begin{array}{l}\text { Few numbers of cells begin to } \\
\text { acquire neural shape and some } \\
\text { cells appear round. }\end{array}$ & $\begin{array}{l}\text { Large number of cells begins } \\
\text { to acquire neural shape. }\end{array}$ & fibroblastic \\
\hline After 14 days & $\begin{array}{l}\text { Some cells have neural like shape } \\
\text { with processes (figure } 2 \text { ). }\end{array}$ & $\begin{array}{l}\text { Large number of cells has } \\
\text { neural like shape with } \\
\text { processes (figure } 3 \text { ). }\end{array}$ & $\begin{array}{l}\text { Spindle, } \\
\text { shape. }\end{array}$ \\
\hline
\end{tabular}




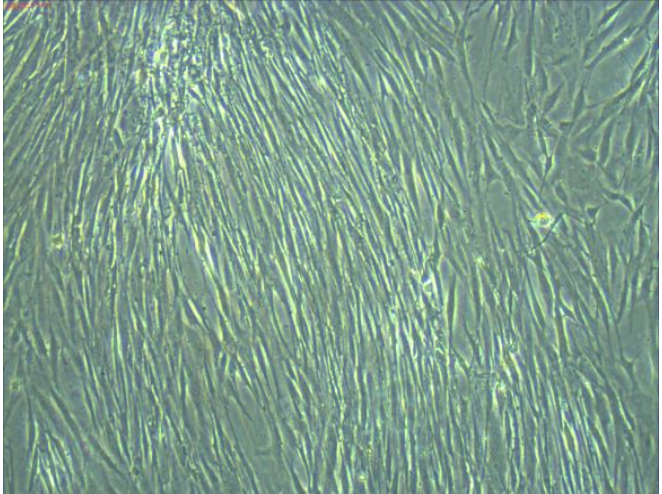

Figure 1: Phase contrast microscopic image after passage three showing transformation of the great majority of cells into spindle shaped mesenchymal stem cells.

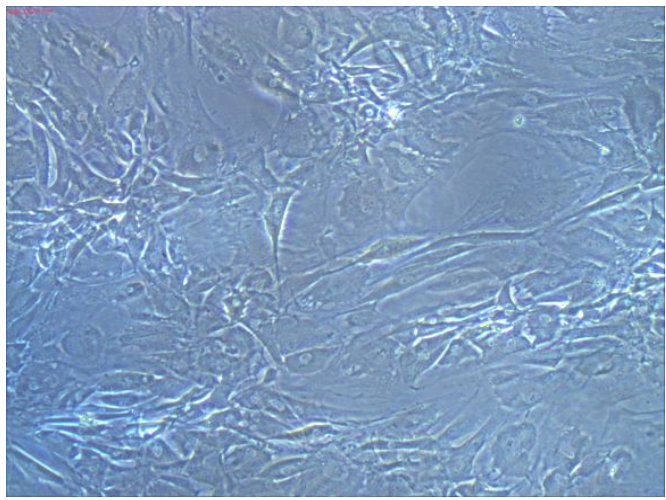

Figure 2: Phase contrast microscopic image showing adipose-derived MSCs after Fourteen days of induction by NI 1 . The cells were differentiated into neural like morphology with processes.

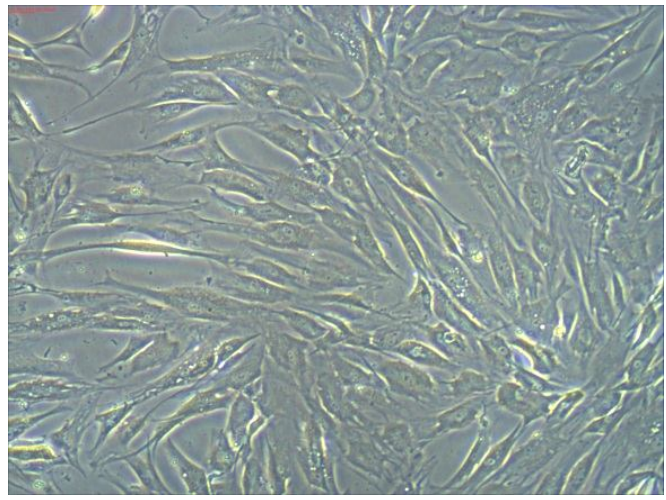

Figure 3: Phase contrast microscopic image showing adipose-derived MSCs after fourteen days of induction by NI 3, neural like cells with large nucleus and associated processes. 
Table 1: The relative expression of $\beta$-tubulin gene was significantly different $(\mathrm{P} \leq 0.05)$ between the two treated neural induction media (NI1 and NI2) as compared to control.

\begin{tabular}{|c|c|c|c|}
\hline & B tubulin CT & Fold change & SE \\
\hline Control & 27.16 & 1.00 & 0.08 \\
\hline NI1 & 26.13 & 2.10 & 0.1 \\
\hline NI2 & 26.93 & 3.05 & 0.11 \\
\hline
\end{tabular}

Table 2: The relative expression of MAP2 gene was significantly different $(\mathrm{P} \leq 0.05)$ between the two treated groups and control.

\begin{tabular}{|c|c|c|c|}
\hline & MAP-CT & fold change & SE \\
\hline Control & 38.08 & 1.00 & 0.08 \\
\hline NI1 & 39.62 & 1.88 & 0.1 \\
\hline NI2 & 35.23 & 2.75 & 0.12 \\
\hline
\end{tabular}

Table 3: The relative expression of Chat gene was significantly different $(\mathrm{P} \leq 0.05)$ between the two treated groups and control.

\begin{tabular}{|c|c|c|c|}
\hline & Chat- CT & fold change & SE \\
\hline Control & 32.79 & 1.00 & 0.08 \\
\hline NI1 & 33.41 & 1.27 & 0.09 \\
\hline NI2 & 32.8 & 1.77 & 0.09 \\
\hline
\end{tabular}

Table 4: The relative expression of $\mathrm{TH}$ gene was significantly different $(\mathrm{P} \leq 0.05)$ between the two treated groups and control.

\begin{tabular}{|c|c|c|c|}
\hline & TH-CT & fold change & SE \\
\hline Cnt & 32.21 & 1.00 & 0.08 \\
\hline NI1 & 31.62 & 2.95 & 0.09 \\
\hline NI2 & 31.27 & 3.41 & 0.09 \\
\hline
\end{tabular}




\section{DISCUSSION}

Stem cell knowledge has become a progressively attractive field to investigate and treat the neurodegenerative disorders since over 20 years ago. Death of neurons in the brain causes most of the neurodegenerative diseases. There are many reasons for neural death, including genetic reasons such as gene mutations, infectious diseases or metabolic reasons such as strokes. Different neurons in the brain are affected differently and so worsen the disease symptoms. The degeneration process can be uncontrollable and unpredictable. Cell replacement using stem cells in our bodies is one of the new hopes to fight the diseases. Stem cells are the "mothers" or "origins" of all cells in our body. Recent discoveries of stem cells particularly the discoveries of stem cells in adult bodies have opened up a great opportunity to apply the stem cells for cellular-based therapy. The concept is very simple: when cells in one part of the body are damaged, our own stem cells will replace them, and help to restore lost function (Furcht, et al., 2011).

Human neural stem cell is a promising source for treatment of neurodegenerative disorders. However, isolation of neural stem cell from brain or other nervous tissues needs an invasive procedure. This has motivated scientists to search for non-invasive cellular sources.

Human adipose tissue is now considered a valuable, abundant, non-tumorigenic and autologous source from which mesenchymal stem cells (MSCs) could be isolated and differentiated into functional neural cells or one of its lineages for replacing the lost ones (Richelieu, 2009).

\section{Morphological analysis:}

In this study, at the first day of isolation, there were heterogonous types of cells such as ASCs, endothelial cells, endothelial progenitor cells, pericytes, smooth muscle cells, erythrocytes and leukocytes which were called stromal vascular fraction (SVF). At the morphological level, the aforementioned cell types at day one of culture were very similar to each other, and we were unable to distingue them morphologically. The cells were spherical in shape, and they were still suspended in the culture media with no attachment to the culture plates. A similar finding was previously reported by (Yoshimura et al., 2006).

On the second and third day of incubation, the adipose-derived MSCs started to attach to plastic surface of the culture flasks, and they exhibited spindle or fibroblastic shapes. Other non-MSCs remain suspended, and maintained their spherical shape. By continuous change of old media, and feeding the cells with fresh media, we succeeded to get rid of most of the non-attached cells, and to obtain a pure culture of attached adiposederived MSCs. This agrees with (Eto et al., 2009) who demonstrated that adipose tissuederived MSCs were started to attach as a separate cell population after overnight incubation in induction media.

After day three, the adipose-derived MSCs continued to increase in number, and confluence, and on the $16^{\text {th }}$ day of incubation, the cells reached a confluence of more than $70 \%$.

In the present study, we suggested that passage 3 of adipose tissue-derived MSCs was ideal to use for other downstream applications (gene expression profiling, ICC, cell-based therapy etc.). This was mainly due to the great reduction in the number of heterogeneous 
suspended cells, and the healthy nature of passage 3 cells that were able to withstand the detachment processes during passage 1 and 2 . Furthermore, older passages may become aged depending the MSC source, and health status of the patients from which samples were obtained.

Here, we have used two types of neuronal induction media, the first one was composed of DMEM supplemented with 10\% FBS, and $10 \mu \mathrm{M}$ retinoic acid (NI 1). Following three days culture in this media, some cells show enlargement with obvious nucleus and few processes begin to appear. By the $6^{\text {th }}$ day of incubation, few numbers of cells begin to acquire neural shape and some cells appear round. On day 14 , the great majority of the cells were induced into neuron-like cells (figure 2). These findings were comparable to those of Mammadov et al. (2011) who demonstrated that using the same media, bone marrow-isolated MSCs started to exhibit neuron-like morphology by the ninth days. This may be due to the difference in MSCs source, patient status, and difference in isolation protocol.

Next, we have induced the MSCS to differentiate into neurons using DMEM supplemented with10\% FBS + 10ng/ml FGF $+50 \mu \mathrm{g} / \mathrm{ml}$ heparin (NI 2). In comparison to our first induction protocol (NI 1), addition of FGF was associated with the formation of more fibroblastic-like cells. Cells enlarged with more obvious processes than observed in NI 2 in the third day. After 6 days, large number of cells begins to acquire neural shape, and by the $14^{\text {th }}$ day, the cells were larger with a clearly visible neural-like morphology (figure 3). These findings were consistent with those of (Hu et al., 2013) who demonstrated that after 15 days of incubation in DMEM supplemented with 10ng FGF+50 $\mu$ g heparin, umbilical cord derived MSCs were induced to form cells with round or elliptical cell bodies. These cells exhibited primary and secondary processes, and were interconnected to one another with neural like morphology.

\section{Molecular analysis:}

Following successful neuronal induction using two different induction protocols, we have confirmed the differentiation of AD-MSCs into neuronal cell lineage at the gene expression level using qualitative and quantitative real time PCR (RT-PCR) technique.

RT-PCR gene expression profiling of AD-MSCs induced neurons by culturing in DMEM supplemented with 10\% FBS, 1\% antibiotic and $10 \mu \mathrm{M}$ retinoic acid (NI 1) revealed significant up-regulation of MAP2, $\beta$ tubulin III, ChAT and TH after 14 days of induction as compared to control group ( undifferentiated MSCs that not treated with induction media ).

MAP2 is a neuron-specific cytoskeletal protein which is considered as a neuronal phenotype marker (Izant and McIntosh, 1980). MAP2 is expressed in both adult and embryonic tissues of the vertebrate nervous system. Expression is weak in neuronal precursors but later becomes pronounced (Dehmelt \& Halpain, 2005), so MAP2 is considered as mature neural marker. Neuronspecific Class III $\beta$-tubulin (TuJ1) is present in newly generated immature postmitotic neurons and differentiated neurons and in some mitotically active neuronal percursors (Und Halbach, 2007). Choline Acetyltransferase (ChAT) is expressed in cholinergic neurons of both CNS and PNS so used as cholinergic marker (Schäfer et al., 1998).TH is an enzyme involved in synthesis of dopamine and norepinephrine. Usually it is used as a marker for dopaminergic neurons (Hartman et al., 1972). These findings clearly indicate successful induction of AD-MSCs into MAP2, 
$\beta$ tubulin III, ChAT, and TH positive neuronal lineage. Our findings agree well with those of Mammadov et al. (2011) who demonstrated that culture of BM-MSC on fibronectin coated cell culture surface with media supplemented with $10 \%$ FBS, $1 \%$ antibiotic and $10 \mu \mathrm{M}$ retinoic acid revealed that RA induced upregulation in $\beta$ tubulin III (immature neural marker) after 2 and 7 days while, NF (mature neural marker) was induced after 14 days. But it had not been reported into which type of neurons differentiation occurs.

Next, in order to identify type of differentiated neurons, we studied the gene expression profile for neuronal-specific genes such as ChAT and $\mathrm{TH}$ which are specific markers for cholinergic and dopaminergic neurons, respectively. The present study revealed upregulation in both markers indicating that retinoic acid might be used as both cholinergic and dopaminergic inducer.

The molecular mechanism by which RA induced the differentiation of MSCs into neurons was previous suggested by Maden (2007) who elucidated that RA induces neural induction through uptake of RA through STRA6 (membrane receptor), bind to CRABP2 (cellular retinoic acid binding protein 2) which assist the entrance of the retinoic acid into the nucleus. In the nucleus, RA bind to the retinoic acid receptors (RAR retinoic acid receptor - and RXR -retinoic $X$ receptor) which subsequently then bind to sequence in DNA called a retinoic acidresponse element (RARE).This binding activate the transcription of the neuronal target genes.

In an attempt to identify, the optimal protocol needed for induction of AD-MSCs into neurons, we used other inductions protocols. The neural induction media used in this study was DMEM supplemented with $10 \% \mathrm{FBS}, 10 \mathrm{ng} / \mathrm{ml} \mathrm{FGF}$ and $50 \mu \mathrm{g} / \mathrm{ml}$ heparin. Heparin combined with FGF increased the expression of $\beta$ tubulin III , MAP 2, ChAT and $\mathrm{TH}$ more than revealed by NI 1 . These findings fit well with those of Liu et al. (2013) who demonstrated that differentiation of umblical cord-derived MSCs into neurons using DMEM supplemented with $10 \mathrm{ng} / \mathrm{ml}$ FGF and $50 \mu \mathrm{g} / \mathrm{ml}$ heparin was associated with upregulation of MAP2 and ChAT gene as compared to control group. The present finding could be also compared with those of Zhang et al.(2011) who demonstrated that heparin promotes the formation of Soxl $(+)$ neural precursor cells from ESCs, and stem cells induced by heparin can differentiate into original ectoderm and neuroepithelium (Volpato et al., 2012). In addition, basic FGF exhibits a high affinity for heparin, and binding of basic FGF to heparin can improve resistance to acid, heat and protease degradation (Jordan et al., 2009).

\section{CONCLUSION}

Heparin mix with FGF is a good dopaminergic, cholinergic inducer which give a better result than using retinoic acid alone.

\section{Acknowledgment:}

First I thanks God for the success of this research. I want to give great thanks to Dr. Mahmoud Gabr who gave a lot of help and advices to success this research and without his effort it would be too hard to conduct this work. Also I want to thank Dr. Mohga Mohamed Alessawy for her usual support and hardwork helping in this research success. Finally I want to thank Dr. Reda El Demerdash for his continuous support. 


\section{REFERENCES}

Dantuma, E., Merchant, S., \& Sugaya, K. (2010). Stem cells for the treatment of neurodegenerative diseases. Stem Cell Res Ther, 1(5), 37.

Dehmelt, L., \& Halpain, S. (2005). The MAP2/Tau family of microtubuleassociated proteins. Genome Biol, 6(1), 204.

Dezawa, M., Takahashi, I., Esaki, M., Takano, M., \& Sawada, H. (2001). Sciatic nerve regeneration in rats induced by transplantation of in vitro differentiated bone-marrow stromal cells. European Journal of Neuroscience, 14(11), 1771-1776.

Eto, H., Suga, H., Matsumoto, D., Inoue, K., Aoi, N., Kato, H., ... \& Yoshimura, K. (2009). Characterization of structure and cellular components of aspirated and excised adipose tissue. Plastic and reconstructive surgery,124(4), 10871097.

Fang, B., Song, Y., Liao, L., Zhang, Y., \& Zhao, R. C. (2007, December). Favorable response to human adipose tissue-derived mesenchymal stem cells in steroid-refractory acute graft-versushost disease. In Transplantation proceedings (Vol. 39, No. 10, pp. 3358-3362). Elsevier.

Feng, Z., Zhao, G., \& Yu, L. (2008). Neural Stem Cells and Alzheimer's Disease: Challenges \& Hope. American journal of Alzheimer's disease and other dementias.

Furcht, L., Hoffman, W., \& Reeve, $B$. (2011). The Stem Cell Dilemma: The Scientific Breakthroughs, Ethical Concerns, Political Tensions, and Hope Surrounding Stem Cell Research. Skyhorse Publishing Inc.
Gimble, J. M. (2003). Adipose tissue-derived therapeutics. Expert opinion on biological therapy, 3(5), 705-713.

Hartman, B. K., Zide, D., \& Udenfriend, S. (1972). The use of dopamine $\beta$ hydroxylase as a marker for the central noradrenergic nervous system in rat brain. Proceedings of the National Academy of Sciences, 69(9), 27222726.

Hu, F., Wang, X., Liang, G., Lv, L., Zhu, Y., Sun, B., \& Xiao, Z. (2013). Effects of epidermal growth factor and basic fibroblast growth factor on the proliferation and osteogenic and neural differentiation of adipose-derived stem cells. Cellular Reprogramming (Formerly" Cloning and Stem Cells"), 15(3), 224-232.

Izant, J. G., \& McIntosh, J. R. (1980). Microtubule-associated proteins: a monoclonal antibody to MAP2 binds to differentiated neurons. Academy of Sciences, 77(8), 47414745.Proceedings of the National.

Jordan, P. M., Ojeda, L. D., Thonhoff, J. R., Gao, J., Boehning, D., Yu, Y., \& Wu, P. (2009). Generation of spinal motor neurons from human fetal brainderived neural stem cells: Role of basic fibroblast growth factor. Journal of neuroscience research, 87(2), 318-332.

Lindvall, O., \& Kokaia, Z. (2010). Stem cells in human neurodegenerative disorders - time for clinical translation?. The Journal of clinical investigation, 120(1), 29-40.

Liu, X., Li, D., Jiang, D., \& Fang, Y. (2013). Acetylcholine secretion by motor neuron-like cells from umbilical cord mesenchymal stem cells. Neural regeneration research, 8(22), 2086. 
Ma, D. K., Bonaguidi, M. A., Ming, G. L., \& Song, $H$. (2009). Adult neural stem cells in the mammalian central nervous system. Cell research, 19(6), 672-682.

Maden, M. (2007). Retinoic acid in the development, regeneration and maintenance of the nervous system. Nature Reviews Neuroscience, 8(10), 755-765.

Mammadov, B., Karakas, N., \& Isik, S. (2011). Comparison of long-term retinoic acid-based neural induction methods of bone marrow human mesenchymal stem cells. In Vitro Cellular \& Developmental BiologyAnimal,47(7), 484-491.

Oyagi, S., Hirose, M., Kojima, M., Okuyama, M., Kawase, M., Nakamura, T., ... \& Yagi, K. (2006). Therapeutic effect of transplanting HGF-treated bone marrow mesenchymal cells into $\mathrm{CCl} 4$ injured rats. Journal of hepatology, 44(4), 742-748.

Prockop, D. J. (1997). Marrow stromal cells as stem cells for nonhematopoietic tissues. Science, 276(5309), 71-74.

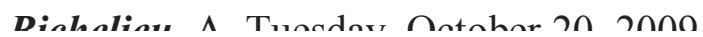

Schäfer, M. H., Eiden, L. E., \& Weihe, E. (1998). Cholinergic neurons and terminal fields revealed by immunohistochemistry for the vesicular acetylcholine transporter. II. The peripheral nervous system. Neuroscience, 84(2), 361-376.

Und Halbach, O.V.B. (2007). Immunohistological markers for staging neurogenesis in adult hippocampus. Cell and tissue research, 329(3), 409-420.

Volpato, F. Z., Almodóvar, J., Erickson, K., Popat, K. C., Migliaresi, C., \& Kipper, M. J. (2012). Preservation of FGF-2 bioactivity using heparin-based nanoparticles, and their delivery from electrospun chitosan fibers. Acta biomaterialia, 8(4), 1551-1559.

Yoshimura, K., Shigeura, T., Matsumoto, D., Sato, T., Takaki, Y., Aiba-Kojima, E.,...\& Gonda, K. (2006). Characterization of freshly isolated and cultured cells derived from the fatty and fluid portions of liposuction aspirates. Journal of cellular physiology, 208(1), 64-76.

Zhang, F., Yang, B., Ly, M., Solakyildirim, K., Xiao, Z., Wang, Z., ... \& Linhardt, R.J. (2011). Structural characterization of heparins from different commercial sources. Analytical and bioanalytical chemistry, 401(9), 2793-2803. 


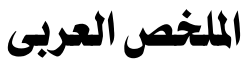

\section{تميز الخلايا الميزنشيمية المستخلصة من النسيج الدهنى الى الخلايا العصبية}

\author{
اية محب الجمل ـ احمد عبلد المقصود ـ امانى فرج ـ هانى السيد مرعى \\ قسم الخليه و الانسجة ـ كلية الطب البيطرى - جامعة المنصورة
}

قدرة الخلايا العصبيه محدودة الاتقسام، يجعل علاج الامراض التى تصيب الجهاز العصبى الأكثر تحديا وصعوبة بين الأمراض المختلفة. حتى الآن، والتدخلات الجراحية والطبية التقليدية يبطىع فقط تطور هذه الأمراض العصبية ولكن عدد الخلايا العصبية لا تزال تنقص فى العديد من المرضى.

الآن، وقد اجتذب العلاج بالخلايا الجذعية الميزنشيميه اهتمام كبير من معظم العلمـاء والأطباء في جميع أنحاء العالم لاستخدامها كمصدر علاجى للامراض العصبية المختلفة. تم العثور على الخلايا الجذعية في جميع أنحاء الجسم، ويمكن الحصول عليها من الأنسجة المختلفة مثل الأنسجة الدهنيـة، ونخـاع العظام والدم. الخلايـا الميزنشيمية تتميز بقدرة عالية على الانقسام و التمايز، وتوفير مصدر للخلايـا العصبية والخلايـا الدبقية للعلاج بالخلايـا. أيضا، الخلايـا الميزنشيمية تظهر تاثيرها العلاجى من دون أي تعديل وراثي و بدون ظهور اورام. في الآونة الأخيرة، وجهت العلمـاء الخلايـا الجذعية الميزنشيمية للتمـايز نحو الخلايـا العصبية باستخدام عوامل النمـو المختلفة والمواد الكيميائية. في الاراسة الحالية، قمنـا باختبار تأثثير الريتينويك اسد والهيبارين و مواد محفزة للنمو كمواد محفزة للتمايز العصبى. وتشير النتـائج إلى أن كـلا مـن حمض الريتينويك والهيبـارين محرضـات عصبية ايجابيـة. وقد تأكدت هذه النتـائج باستخدام جهاز تفاعل البلمرة المتسلسل الكمى لبعض الجينات العصبية المميزة. 